
growth performance and carcass quality in intact male pigs

\author{
INAUGURAL-DISSERTATION
}

zur Erlangung der Doktorwürde der Vetsuisse-Fakultät Universität Zürich

\author{
vorgelegt von \\ Patricia Jaros \\ Tierärztin \\ von Bremgarten AG
}

genehmigt auf Antrag von

Prof. Dr. R. Thun, Referent

PD Dr. K.D.C. Stärk, Korreferentin

Zürich 2004

Zentralstelle der Studentenschaft 


\title{
Effect of active immunization against GnRH on androstenone concentration, growth performance and carcass quality in intact male pigs
}

\author{
P. Jaros ${ }^{1}$, E. Bürgi ${ }^{1}$, K.D.C. Stärk ${ }^{2}$, R. Claus ${ }^{3}$, D. Hennessy ${ }^{4}$, R. Thun ${ }^{1}$ \\ ${ }^{1}$ Department of Farm Animals, Faculty of Veterinary Medicine, University of Zürich, \\ 8057 Zürich, Switzerland \\ ${ }^{2}$ Federal Veterinary Office, 3003 Bern, Switzerland \\ ${ }^{3}$ Institute for Animal Husbandry and Animal Breeding, University of Hohenheim, \\ 70599 Stuttgart, Germany \\ ${ }^{4}$ CSL Ltd, Parkville, Victoria 3052, Australia
}

\begin{abstract}
The objective of this study was to investigate the efficacy of active immunization against gonadotropin releasing hormone $(\mathrm{GnRH})$ in male pigs and to compare it with surgical castration. Piglets were randomly assigned to two groups, one of 263 animals for surgical castration (SC) and one of 270 animals for immunocastration (IC). Surgery was done at 14 days of age and vaccination (Improvac ${ }^{\circledR}, \mathrm{CSL}$, Australia) performed twice at an interval of 4 to 5 weeks with the second injection given 4 to 7 weeks before slaughter. At slaughter, testes were weighed and fat samples collected for androstenone analysis. Androstenone was tested olfactorially by heating salivary glands in a microwave oven. Daily growth rate and meat quality were assessed in all animals. Regarding mean androstenone concentrations in backfat, no significant difference was found between SC and IC $(0.042(0.041 ; 0.044) \mu \mathrm{g} / \mathrm{g}$ vs. $0.058(0.044 ; 0.071) \mu \mathrm{g} / \mathrm{g}$; mean $(95 \%$ confidence interval)). Testes weight was significantly $(\mathrm{P}<0.001)$ smaller in immunized (230.8 $(218.23 ; 243.52) \mathrm{g})$ as compared to normal boars $(761.8(722.77 ; 801.01) \mathrm{g})$ of the same age, as a reference. In this study, androstenone production was suppressed in all vaccinated animals and the carcasses given free for consumption. Mean daily growth gain was not significantly different between SC $(0.817(0.804 ; 0.830) \mathrm{kg})$ and IC $(0.827(0.814 ; 0.840) \mathrm{kg})$, although there was a trend for better performance in the latter group. The yield of lean meat was significantly $(\mathrm{P}<0.001)$ improved in IC $(54.50(54.26 ; 54.73) \%)$ when compared to SC $(53.76(53.53 ; 54.00)$ $\%)$. From our results, we conclude that vaccination against $\mathrm{GnRH}$ is a practical and effective method to suppress androstenone synthesis. Pain and stress associated with surgical castration can thus be avoided.
\end{abstract}

Key words: Immunocastration, GnRH, androstenone, boar taint, pig 


\section{Auswirkungen einer aktiven Immunisierung gegen GnRH auf die Androstenon-Konzentration, Gewichtszunahme und Schlachtkörperqualität beim männlichen Schwein}

\section{Zusammenfassung}

Das Ziel dieser Studie war, die Wirkung der aktiven Immunisierung gegen das Gonadotropin Releasing Hormon (GnRH) bei männlichen Schweinen zu untersuchen und mit der chirurgischen Kastration zu vergleichen. Ferkel wurden randomisiert und in zwei Gruppen unterteilt: 263 Tiere für die chirurgische Kastration (SC) und 270 für die Immunokastration (IC). Der chirurgische Eingriff wurde in den ersten 14 Lebenstagen durchgeführt und die Impfung mit Improvac ${ }^{\circledR}, \mathrm{CSL}$, Australia, zweimal im Abstand von 4 bis 5 Wochen; die zweite Impfung (Booster) erfolgte 4 bis 7 Wochen vor dem geplanten Schlachttermin. Bei der Schlachtung wurde das Hodengewicht gewogen und Fettproben für die Bestimmung von Androstenon gesammelt. Zusätzlich wurde Androstenon auch olfaktorisch nach Erhitzung der Speicheldrüsen im Mikrowellenofen getestet. Weiter wurden die Tageszuwachsrate und Fleischqualität aller Tiere bestimmt. Die durchschnittliche Androstenon- Konzentration im Rückenfett beider Gruppen (SC und IC) wies keine signifikanten Unterschiede auf $(0.042(0.041 ; 0.044) \mu \mathrm{g} / \mathrm{g}$ vs. $0.058(0.044 ; 0.071) \mu \mathrm{g} / \mathrm{g}$; Durchschnitt (95\% Konfidenzinterval). Das Hodengewicht von immunisierten Ebern war signifikant $(\mathrm{P}<0.001)$ kleiner $(230.8(218.23$; 243.52) g) als bei normalen Ebern gleichen Alters (761.8 (722.77; 801.01) g). In dieser Studie konnte bewiesen werden, dass die Androstenon Produktion in allen geimpften Tieren deutlich gehemmt war und alle Schlachtkörper konsumtauglich waren. Der durchschnittliche Tageszuwachs war zwischen SC (0.817 (0.804; $0.830) \mathrm{kg})$ und IC $(0.827(0.814 ; 0.840) \mathrm{kg})$ nicht signifikant verschieden, obwohl letztere Gruppe eine bessere Zuwachsrate zeigte. Der Magerfleischanteil war bei IC (54.50 (54.26; $54.73) \%)$ im Vergleich zu SC (53.76 (53.53; 54.00) \%) signifikant $(\mathrm{P}<0.001)$ erhöht. Aus unseren Ergebnissen kann gefolgert werden, dass die Impfung gegen GnRH eine praktische und effiziente Methode ist, um die Androstenon Synthese erfolgreich zu unterdruecken. Angst und Stress, die vor allem bei der chirurgischen Kastration auftreten, können auf diese Weise vermieden werden. 


\section{Introduction}

Consumption of pig meat in Switzerland has continuously increased over the last years (Statistische Erhebungen und Schätzungen, 2003, Schweiz. Bauernverband, Brugg). This development is mainly the result of improved meat quality while keeping the production costs at a low level. Besides lean carcass production, the consumers also demand pork which is free of distinct boar taint. This unpleasant urine-like odour is mainly caused by androstenone, a testicular steroid that accumulates in fat tissue (Patterson, 1968). Another contributor of boar taint is skatole, but contrary to androstenone, this substance is not entirely male-specific being a product of microbial tryptophan breakdown in the gut. In addition, skatole formation is not directly linked to testicular function so that high androstenone concentrations $(>0.5 \mu \mathrm{g} / \mathrm{g}$ fat $)$ were found in around $60 \%$ of the boars, but high skatole levels $(>0.22 \mu \mathrm{g} / \mathrm{g}$ fat $)$ only in $11 \%$ in a large EU-study (Bonneau et al., 2000). Nevertheless skatole accumulation is specifically favoured in males by testicular steroids, either by influencing gut mucosa turnover and thus supply of substrate for microbial processes (Raab et al, 1998) or by inhibiting liver metabolism by skatole (Zamaratskaia, 2004). Recent studies (Claus et al. 2003; Zamaratskaia, 2004) reveal that skatole accumulation can be easily inhibited by feeding strategies and also influenced by special housing conditions (Claus et al., 1996).

Although intact boars have better growth performance and produce leaner carcass than castrates, surgical gonadectomy of male piglets is common practice in pig farming world-wide in order to prevent the occurrence of boar taint. In Switzerland, according to the Swiss Federal Ordinance on Animal Protection, surgical castration is allowed to be performed by the farmer within the first 14 days of life without anaesthesia. This technique, however, is known to be associated with pain or stress independent of the animal's age. For that reason it is not surprising that during the last years, animal welfare organizations accused routine castration without anaesthesia as being a cruel and painful procedure. Influenced by animal welfare concern and some disadvantages of surgical castration (hemorrhage, infection) the Federal Veterinary Office has decided to support various projects which are all aimed at developing more acceptable and animal-friendly methods for practical application. Alternative techniques to prevent consumer reactions due to boar taint comprise the development of a chemical device ("chemical nose") to detect androstenone and other odorous steroids for the sorting out of tainted carcasses (Annor-Frempong et al., 1998). Furthermore, considerable research has also been conducted with various gaseous anaesthetic agents to reduce or eliminate the pain of surgical castration (Kohler et al., 1998). Another approach of improving meat quality and at the same time representing a method to influence 
reproductive and behaviour characteristics of pigs is based on vaccination against gonadotropinreleasing hormone $(\mathrm{GnRH})$. This approach is the topic of this article.

GnRH is a small peptide (decapeptide) originating in the hypothalamus acting on the anterior pituitary to induce the secretion of LH and FSH. These two gonadotropins act upon the gonads to stimulate testis growth and steroidogenesis. Testicular steroids, e.g. testosterone, are subsequently released into the circulation and transported to various tissues where they serve diverse functions including feedback regulation of GnRH, LH and FSH secretion, development of male sex characteristics as well as enhancement of muscle growth. Another steroid is androstenone ( $5 \alpha$-androst-16-en-3-one) which is not androgenic but is stored in fat tissue and in part responsible for the unpleasant boar taint. Accordingly, immunization against GnRH will disrupt the hypothalamic-pituitary-gonad axis, thereby inhibiting testis growth and steroid synthesis which will finally also reduce the occurrence of boar odour. Inhibition of fertility by immunization against GnRH (immunocastration) has been successful in many animal species using various vaccine preparations (Carelli et al., 1985; Goubau et al., 1989; Adams et al., 1996; Dowsett et al., 1996; Janett et al., 2003).

Because GnRH itself is too small to be immunogenic, it must be coupled with a carrier protein along with the use of an adjuvant. In pigs, GnRH-immunization to suppress offensive boar taint has first been reported by Falvo et al. (1986) and Caraty and Bonneau (1986) and later by other investigators (Bonneau et al., 1994; Oonk et al., 1998; Beekman et al., 1999; Zeng et al., 2001). All authors used various conjugates, adjuvants and vaccination schedules. In farm animals, especially pigs, a GnRH-vaccine for commercial use must be economic and highly immunogenic to induce a sufficient titre of neutralizing anti-GnRH antibodies with only few injections needed. Furthermore, vaccination must be well-tolerable for the animal and most importantly, the components of the vaccine have to be safe and acceptable by the consumers. Recently, a vaccine has been developed in Australia that contains a modified form of $\mathrm{GnRH}$ with an aqueous adjuvant added. Vaccination is performed twice, 4 weeks apart, with the second injection given 5 to 6 weeks before slaughter (Dunshea et al., 2001).

The aim of the present study was to investigate the efficacy of Improvac ${ }^{\circledR}$ in two swine herds under practical conditions and to compare testes weight, androstenone concentration in fat, boar taint as well as growth performance and meat quality between immunized entire male pigs and surgically castrated male pigs. 


\section{Materials and methods}

\subsection{Animals and experimental design}

For this study, a total of 533 male pigs (16\% Swiss Landrace x Swiss Large White, 15\% Swiss Large White x Swiss Landrace-Swiss Large White, 27\% Swiss Large White x Swiss Large White, 27\% Duroc x Swiss Large White, 15\% Duroc x Swiss Landrace-Swiss Large White) from two different breeding farms located in the western part of Switzerland were used. After parturition, male piglets of each litter were randomly assigned to two groups with a total of 270 animals for immunocastration (IC) and 263 animals for surgical castration (SC, controls) within the first 14 days of life. Litter effects were controlled by randomly assigning male piglets of each litter to both groups. The sample size was calculated such that a difference in proportion of tainted carcasses of at least $3 \%$ could be detected on the $95 \%$ confidence level with a power of $80 \%$. Required sample size of each group was 256.

After weaning at a weight of $25 \mathrm{~kg}$, all littermates (intact males and barrows) were transported to two different farms (1 and 2) for the fattening period. Upon arrival in the new farms, all pigs were weighed and kept in pen-groups of 10 animals, independent of their sex. Pigs were fed three times a day a commercial feed together with whey in a ratio of 1 to 4 . The diet ration included 13.8 MJ metabolizable energy per kg dry matter (DM) and $18.5 \%$ crude protein (CP) per $\mathrm{kg}$ MD. The animals had free access to water. All pigs were additionally weighed at days of vaccination and one day before slaughter. Thus, the daily growth rate for animals of both treatment groups could be calculated for the whole fattening period.

\subsection{Vaccine and immunization protocol}

For our experiments, active immunization against GnRH was performed using the vaccine Improvac $^{\circledR}$ (CSL Ltd, Parkville, Victoria, Australia) containing a modified form of GnRH (200 $\mu \mathrm{g}$ GnRH-protein conjugate/ml) in an aqueous adjuvant system. Pigs were vaccinated twice at an interval of at least 4 to 5 weeks with the second dose being given 4 to 6 weeks prior to slaughter. $2 \mathrm{ml}$ of Improvac ${ }^{\circledR}$ were injected subcutaneously behind the base of the ear using the original Improvac $^{\circledR}$ vaccinator system. By this method no tissue irritation was observed. Expecting a body weight between 100 to $110 \mathrm{~kg}$ at slaughter, the two Improvac ${ }^{\circledR}$ doses in farm 1 were injected when pigs had a body weight of approximately $48 \mathrm{~kg}$ (average age of 16 weeks) and 77 $\mathrm{kg}$ (average age of 21 weeks) and in farm 2 at $37 \mathrm{~kg}$ (average age of 14 weeks) and $64 \mathrm{~kg}$ (average age of 20 weeks), respectively. This difference in vaccination timing took into account different growth performances between the two farms. 


\subsection{Measurements at slaughter}

The animals were slaughtered at 100 to $110 \mathrm{~kg}$ bodyweight using low voltage electrical stunning. Reproductive organs were removed, trimmed and both testes with epididymes weighed. For comparison of testes weight, 77 intact boars of the same age were used as reference. Samples of fat were taken in the neck area and immediately deep-frozen $\left(-20^{\circ} \mathrm{C}\right)$ for subsequent measurements of androstenone concentrations. Carcass weight was recorded $30 \mathrm{~min}$. after slaughter (Bonneau et al., 1994). Lean meat expressed as \% of carcass weight was measured using an ultrameter (CSB-ultra-meater, CSB-System). To determine olfactory perception of androstenone taint, the salivary glands of all pigs (IC, SC) were heated in a microwave oven (Micromat 700, AEG) on the highest temperature level $\left(90^{\circ} \mathrm{C}\right)$ during $2 \mathrm{~min}$., then cut and olfactorially assessed by two persons according to 5 androstenone-related taint-levels $(0=$ none, $1=$ negligible, 2 = little, 3 = modest, 4 = distinct).

\subsection{Androstenone analysis}

All fat samples were analysed by enzyme-immunoassay (EIA) as described by Claus et al., 1997. Tissue samples of about 0.5 to $1.0 \mathrm{~g}$ were heated for $4 \mathrm{~min}$. at 200 watt in a microwave oven. The liquid fat $(100 \mu \mathrm{l})$ was collected and mixed with methanol $\left(900 \mu \mathrm{l}, 50^{\circ} \mathrm{C}\right)$ on a vortex mixer, then cooled down to room temperature (about $20^{\circ} \mathrm{C}$, for $20 \mathrm{~min}$.) to obtain a supernatant containing androstenone. $100 \mu \mathrm{l}$ of this supernatant were mixed with $0.9 \mathrm{ml}$ assay buffer and $100 \mu \mathrm{l}$ of that mixture were directly pipetted into the wells of antibody coated microtitre plates (Claus et al., 1988). The sensitivity of the EIA was $0.04 \mu \mathrm{g}$ androstenone per $\mathrm{g}$ fat. The mean intra- and interassay coefficients of variation were $11.5 \%$ and $13.9 \%$, respectively.

\subsection{Statistical analysis}

The issue of interest was the comparison of different outcome variables between the two treatments IC and SC (controls). Outcome variables were analysed using descriptive statistics. Where applicable, results are reported as mean values together with the $95 \%$ confidence interval (95\% LCL; UPL). Androstenone concentrations $<0.04 \mu \mathrm{g} / \mathrm{g}$ fat were replaced by the sensitivity threshold value of 0.04 (left-censoring). Univariate comparisons between treatments were conducted for the following continuous outcomes: androstenone concentration $[\mu \mathrm{g} / \mathrm{g}$ fat], growth performance $[\mathrm{kg} / \mathrm{day}]$, lean meat [\% of carcass weight] and testes weight [g] using non parametric methods (Mann-Whitney U-test). Univariate comparisons between treatments were conducted for boar taint [scores 0 to 4] using Chi Square-test. Two-sided testing was used throughout. Multivariate analyses were conducted using analysis of variance for data of growth 
performance and lean meat proportion. Outcome variables were normally distributed and did not require transformation. The factors "farm", "litter" and "treatments" were included in the analysis as well as main interaction terms. $\mathrm{P}<0.05$ was considered statistically significant. All statistical analyses were performed with the software package NCSS (Number Cruncher Statistical System 2001, Kaysville, Utah).

\section{Results}

3.1. Androstenone concentrations in fat and boar taint

In both farms, there was a balanced number of animals in the two groups (IC vs. SC). In Farm 1, 132 SC and 135 IC animals were included, and in Farm 2, 131 SC and 135 IC animals were present. Androstenone levels between surgical castrates and immunocastrates were not significantly different (Table 1). The majority of immunocastrates were far below the $0.5 \mu \mathrm{g}$ androstenone/g which is the boar taint threshold level accepted by the European Union (EU, Meat Hygiene Ordinance, annex 1, chapter 4, 2.3.). When looking at individual concentrations, only 2 out of 270 immunocastrates had androstenone values above the EU-threshold (1.4 and 1.0 $\mu \mathrm{g} / \mathrm{g}$ fat, respectively).

Results assessed by heating the salivary glands are presented in Table 1 . More than $98 \%$ SC and $90 \%$ IC had no androstenone-related odour and none of the animals tested had a distinct odour (level 4). Figure 1 demonstrates the relationship between various odour levels as assessed at slaughter and androstenone concentrations of each animal in both, the IC and SC groups. Both immunocastrated pigs with values $>0.5 \mu \mathrm{g} / \mathrm{g}$ fat had boar taint level 3, which is accepted for normal food consumption in Switzerland. 


\section{Table 1}

Concentrations and scores of androstenone, growth performance and lean meat in surgical castrated (SC) and immunocastrated pigs (IC) at slaughter.

\begin{tabular}{|c|c|c|c|c|}
\hline & & $\begin{array}{c}\mathrm{SC} \\
\mathrm{n}=263\end{array}$ & $\begin{array}{c}\mathrm{IC} \\
\mathrm{n}=270\end{array}$ & $\mathrm{P}$ \\
\hline \multirow{4}{*}{ Androstenone $(\mu \mathrm{g} / \mathrm{g}$ fat $)$} & mean & 0.042 & 0.058 & \multirow{4}{*}{$0.111^{1}$} \\
\hline & $\mathrm{LCL}^{4}$ & 0.041 & 0.044 & \\
\hline & $\mathrm{UCL}^{4}$ & 0.044 & 0.071 & \\
\hline & $\mathrm{SD}^{4}$ & 0.013 & 0.109 & \\
\hline \multirow{5}{*}{ Androstenone scores $0-4^{2} \mathrm{n}(\%)$} & 0 & $259(98.5)$ & $243(90.0)$ & \multirow{5}{*}{$0.000^{3}$} \\
\hline & 1 & $4(1.5)$ & $18(6.7)$ & \\
\hline & 2 & $0(0.0)$ & $5(1.8)$ & \\
\hline & 3 & $0(0.0)$ & $4(1.5)$ & \\
\hline & 4 & $0(0.0)$ & $0(0.0)$ & \\
\hline \multirow{4}{*}{ Growth performance (kg/day) } & mean & 0.817 & 0.827 & \multirow{4}{*}{$0.353^{1}$} \\
\hline & LCL & 0.804 & 0.814 & \\
\hline & UCL & 0.830 & 0.840 & \\
\hline & SD & 0.107 & 0.107 & \\
\hline \multirow{4}{*}{ Lean meat ( $\%$ of carcass weight) } & mean & 53.76 & 54.50 & \multirow{4}{*}{$0.000^{1}$} \\
\hline & LCL & 53.53 & 54.26 & \\
\hline & $\mathrm{UCL}$ & 54.00 & 54.73 & \\
\hline & SD & 1.919 & 1.960 & \\
\hline
\end{tabular}

${ }^{1}$ Mann-Whitney U-test, two-sided

${ }^{2} 0=$ none, $1=$ negligible, $2=$ little, $3=$ modest, $4=$ distinct

${ }^{3}$ Chi Square-test; percentages are given between brackets

${ }^{4} \mathrm{LCL}=$ lower $95 \%$ confidence limit; UCL $=$ upper $95 \%$ confidence limit; $\mathrm{SD}=$ standard deviation 


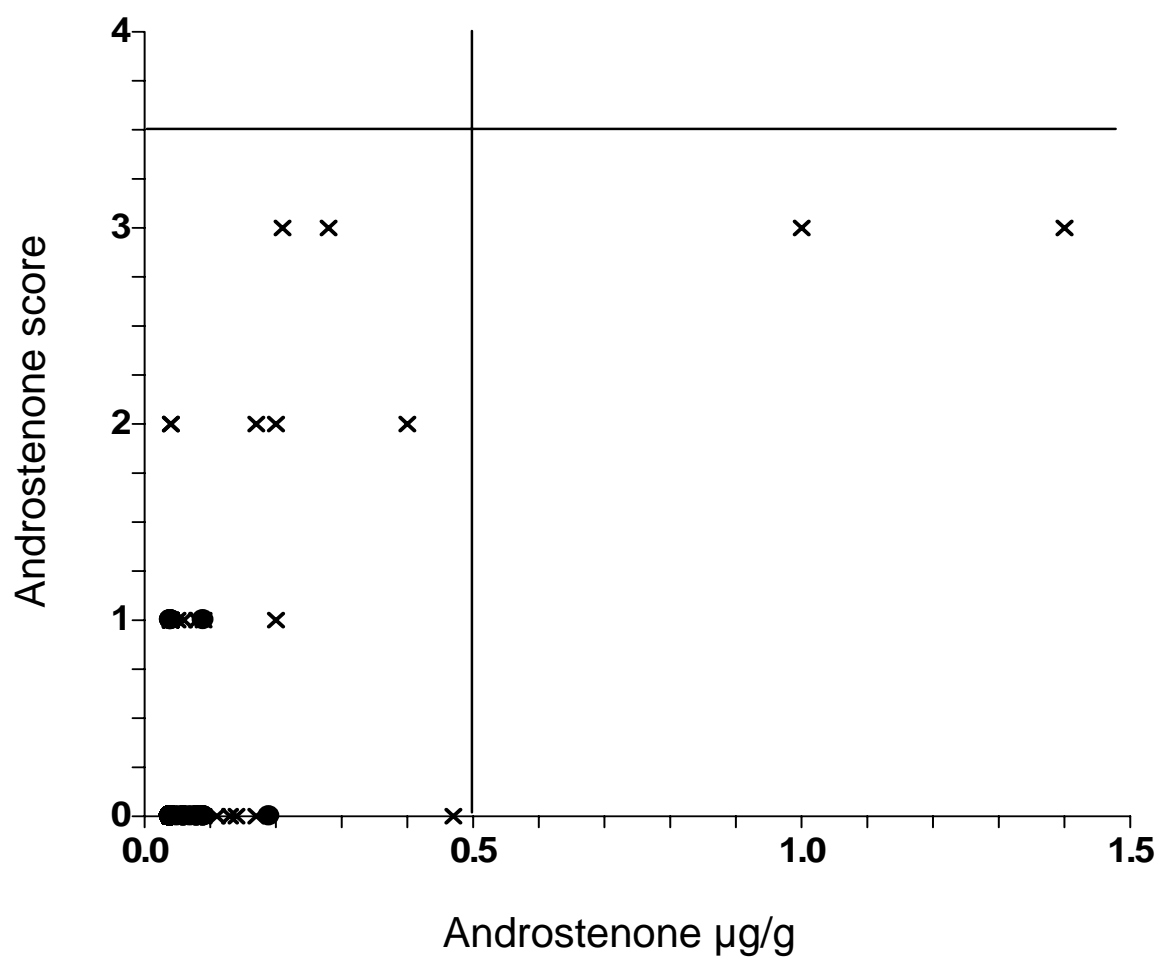

Fig.1. Relationship between olfactorially assessed androstenone scores (0 - 4) and androstenone concentrations $(\mu \mathrm{g} / \mathrm{g}$ fat; sensitivity threshold $0.04 \mu \mathrm{g} / \mathrm{g})$ in surgical castrated $(\bullet, \mathrm{n}=263)$ and immunocastrated pigs $(\mathrm{x}, \mathrm{n}=270)$. Threshold value of $0.5 \mu \mathrm{g} / \mathrm{g}$ fat for androstenone (EU accepted) and $\leq 3$ for androstenone score represent acceptance values.

\subsection{Growth performance, lean meat and testes weight}

The daily weight gain during the fattening period was not significantly different between both groups (Table 1). Surgical castrates had a slightly lower mean daily growth rate when compared to immunocastrates. This effect was also not statistically significant when tested by ANOVA where only the effect of litter was statistically significant $(\mathrm{F}=2.458, \mathrm{P}<0.001)$ but not the effect of immunocastration $(\mathrm{F}=0.664, \mathrm{P}=0.240)$ or farm $(\mathrm{F}=1.449, \mathrm{P}=0.230)$. All interaction terms were not significant at the $\mathrm{P}=0.05$ level. As shown in Table 1 , average lean meat was significantly higher in immunocastrates when compared to surgical castrates. This was confirmed by ANOVA were the effect of immunocastration was highly significant $(\mathrm{F}=23.372, \mathrm{P}<0.001)$. In the same analysis, the effect of litter was also significant $(\mathrm{F}=1.869, \mathrm{P}<0.001)$, but not the effect of farm $(\mathrm{F}=0.206, \mathrm{P}=0.650)$. Interactions involving type of castration were all not statistically significant indicating independence of the effect of immunocastration from the factors "farm" and "litter". Comparison of testes weight between 77 boars of the same age (24-26 weeks) as the immunocastrated pigs $(n=270)$ showed clear differences. Immunocastrates had a significantly 
lower $(\mathrm{P}<0.001)$ mean testes weight $(230.88 \mathrm{~g}(218.23 ; 243.52))$ than control boars $(761.89 \mathrm{~g}$ $(722.77 ; 801.01))$.

\section{Discussion}

Our study demonstrates that castration of male pigs can successfully be performed by active immunization against GnRH. This method therefore represents an effective and practical alternative to surgical castration. In Switzerland, the latter method is still allowed in piglets without anaesthesia during the first 14 days of life. As suggested by the vaccine manufacturer (CSL Ltd, Parkville, Victoria, Australia), Improvac ${ }^{\circledR}$ was given in two doses at an interval of 4 weeks. The second dose which elicits an immune reaction with high antibody titres against GnRH should be given no later than 4 to 5 weeks prior to slaughter to allow any androstenone to be eliminated. Although this vaccination regimen has been shown to be quite effective (Dunshea et al., 2001), other strategies prolonging the interval between both vaccinations to 8 weeks (Meloen et al., 1994; Oonk et al., 1998; Turkstra et al., 2002) or vaccinating three times with intervals of 6 weeks (Metz et al., 2002) have also been reported. In our study the time of the first vaccination and the interval between the second vaccination and slaughter were shown to depend mainly on management and pig fattening traits in each farm.

The immunization effect of Improvac ${ }^{\circledR}$ was best shown by androstenone concentrations in body fat, which fluctuated well below the threshold value of $0.5 \mu \mathrm{g} / \mathrm{g}$ fat, with a mean value of 0.058 $\mu \mathrm{g} / \mathrm{g}$ fat $(0.044 ; 0.071)$ in immunocastrated pigs vs. $0.042 \mu \mathrm{g} / \mathrm{g}$ fat $(0.041 ; 0.044)$ in surgically castrated pigs. Out of 270 immunocastrated pigs, only 2 animals being slaughtered 7.5 and 4.5 weeks after the booster injection had values of 1.0 and $1.4 \mu \mathrm{g} / \mathrm{g}$ fat, respectively. These androstenone values were also reflected by high testicular weights of $705 \mathrm{~g}$ and $490 \mathrm{~g}$, respectively and thus would have been easily detected at the slaughterline. Although the booster vaccinations in both animals were performed correctly in time, the reason for the differing results may most likely be the lack of immunological response known to be variable between individuals.

Androstenone has been known for many years to be responsible for the unpleasant urine-like odour in boars (Claus, 1979). It is stored in fat tissue and is also intensively accumulated in salivary glands. Therefore, testing boar taint by heating the salivary glands in a microwave oven represents a very sensitive olfactorial method for androstenone detection. The classification of the odour, however, remains subjective and depends entirely on the person performing the test. In our study, testing the animals at slaughter was always performed by the same three persons (2 female and 1 male) known to be very sensitive to adult boar fat odour. Figure 1 shows the strong relationship between measured androstenone concentrations in fat tissue and the olfactorial test 
results when using 5 grades of sensation. Not surprisingly, both animals with androstenone values above $0.5 \mu \mathrm{g} / \mathrm{g}$ fat were also detected olfactorially as having boar taint, clearly demonstrating the reliability of the test.

Growth performance in immunocastrated and surgical castrated pigs during the whole fattening period was not significantly different between both groups. In another study (Hennessy et al., 2000; Cronin et al., 2003) it was shown that immunocastrated animals had a significant increased daily weight gain compared to boars, when only the last 4 weeks of the fattening period was considered. The better performance was most likely the result of prolonged anabolic influence before slaughter. In our study, immunocastrated and surgically castrated pigs were not kept separately during the whole fattening period.

Comparing the meat quality between animals of both groups, the percent of lean meat was significantly higher in IC than in SC. This aspect should be considered in meat production industry as lean meat is accepted as a quality parameter with direct financial advantages for the farmer. Additional carcass quality characteristics such as intramuscular fat, colour of the meat and drip loss were also improved in immunocastrates compared to surgical castrates (Hennessy et al., 2000).

From a clinical and practical point of view, the effect of Improvac ${ }^{\circledR}$ is clearly visible in response to the second vaccination. During a period of 4 to 7 weeks duration, testes weight in IC decreased to an average of $230.88 \mathrm{~g}(30.3 \%)$ compared to normal testes weight in boars of $761.89 \mathrm{~g}$ $(100 \%)$. Testes of a larger size weighing up to $500 \mathrm{~g}(\mathrm{n}=7)$ may produce more androstenone, but in our study, the concentration in fat tissue was nearly always well below $0.5 \mu \mathrm{g} / \mathrm{g}$ fat. Only 2 animals with testes $>500 \mathrm{~g}$ had androstenone concentrations above $1 \mu \mathrm{g} / \mathrm{g}$ fat with a positive olfactorial test at slaughter. Most importantly, however, the carcasses of both animals were still acceptable for consumption. As an objective method for boar taint characterization is still lacking, it would depend on the experience of meat inspectors to decide at which testicular size an olfactorial test would be indicated. The occurrence of testes weight differences at slaughter may either be the result of a prolonged interval between the booster injection and slaughter, or differences in testicular size already present at the time of the booster injection. Our results show that a time period of 4 to 7 weeks between the second vaccination and slaughter was not detrimental for the immunization effect. The question when testicular growth would start again after only one booster injection was not part of our study. Published results in sheep (Janett et al., 2003) indicate that reversibility after vaccination may be individually determined and occurs at different time periods after vaccination.

In summary, immunocastration with Improvac ${ }^{\circledR}$ was used in pigs for the first time in Switzerland. Vaccination twice 8 and 4 weeks before slaughter was demonstrated to be an effective and 
practical method to suppress androstenone production. Vaccination is believed to be animal friendly, causing minimal stress and fear, however, this remains to be demonstrated by specific studies. Correct information of consumers and farmers must be given priority before considering the introduction of this method in Switzerland.

\section{Acknowledgements}

The authors are grateful to the Federal Veterinary Office, Bern, Switzerland, for the financial support of the project and thank CSL Ltd., Parkville, Australia for providing the vaccine. The authors would also like to thank Mr. M. Kiser, Mr. O. Felder and Mr. F. Ruffieux for providing the animals and for their cooperation. Special thanks go to Mrs. S. Stäbler (Institute of Veterinary Parasitology, Zürich) for laboratory help, and Mr. Zöbel (Carnex AG) and Mr. Bütikofer (Prosus Co.) for carcass distribution. Finally we would also like to thank Mr. Hofer and his crew of the slaughter house of Zürich. 


\section{References}

Adams, T.E., Daley, C.A., Adams, B.M., Sakurai, H., 1996. Testes function and feedlot performance of bulls actively immunized against Gonadotropin-Releasing Hormone: Effect of age at immunization. J. Anim. Sci. 74, 950-954.

Annor-Frempong, I.E., Nute, G.R., Wood, J.D., Whittington, F.W., West, A., 1998. The measurement of the responses to different odour intensities of 'boar taint' using a sensory panel and an electronic nose. Meat Sci. 50, 139-151.

Beekman, N.J.C.M., Schaaper, W.M.M., Turkstra, J.A., Meloen, R.H., 1999. Highly immunogenic and fully synthetic peptide-carrier constructs targetting GnRH. Vaccine 17, 20432050.

Bonneau, M., Dufour, R., Chouvet, C., Roulet, C., Meadus, W., Squires, E.J., 1994. The effects of immunization against luteinizing hormone-releasing hormone on performance, sexual development, and levels of boar taint-related compounds in intact male pigs. J. Anim. Sci. 72, 14-20.

Bonneau, M., Kempster, A.J., Claus, R., Claudi-Magnussen, C., Diestre, A., Tornberg, E., Walstra, P., Chevillon, P., Weiler, U., Cook, G. L., 2000. An international study on the importance of androstenone and skatole for boar taint: I. Presentation of the programme and measurement of boar taint compounds with different analytical procedures. Meat Sci. 54, 251260.

Caraty, A., Bonneau, M., 1986. Effect of active immunization against gonadorelin on LH and FSH secretion and the fat androstenone level in entire male pigs. C. R. Acad. Sci. Paris Ser. D, 303, 673-676.

Carelli, C., Ralamboranto, L., Audibert, F., Gaillard, J., Briquelet, N., Dray, F., Fafeur, V., Haour, F., Chedid, L., 1985. Immunological castration by a totally synthetic vaccine: Modification of biological properties of LH-RH after conjugation to adjuvant-active muramyl peptide. Int. J. Immunopharmac. 7, 215-224.

Claus R., 1979. The boar taint as model of a steroidal pheromone. Acta Endocrinol. (Copenh.) 91 Suppl. 225, 432-433.

Claus, R., Mahler, G., Münster, E., 1988. Determination of the boar taint steroid $5 \alpha$-androst-16en-3-one in adipose tissues of pigs with a rapid microtitre plate enzyme-immunoassay (MTA). Arch. Lebensmittelhyg. 39, 87-90.

Claus, R., Raab, S., Röckle, S., 1996. Skatole concentrations in blood plasma of pigs as influenced by the effects of dietary factors on gut mucosa proliferation. J. Anim. Physiol. a. Anim. Nutr. 76, 170-179. 
Claus, R., Herbert, E., Dehnhard, M., 1997. Comparative determination of the boar taint steroid androstenone in pig adipose tissue by a rapid enzyme immunoassay and an HPLC-method. Arch. Lebensmittelhyg. 48, 27-30.

Claus, R., Lösel, D., Lacorn, M., Mentschel, J., Schenkel, H., 2003. Effects of butyrate on apoptosis in the pig colon and its consequences for skatole formation and tissue accumulation. J. Anim. Sci., 81, 239-248.

Cronin G.M., Dunshea F.R., Butler K.L., McCauley I., Barnett J.L., Hemsworth P., 2003. The effects of immuno- and surgical-castration on the behaviour and consequently growth of grouphoused, male finisher pigs. Appl. Anim. Behav. Sci., 81, 111-126.

CSL Techincal Update. Improvac ${ }^{\mathrm{TM}}$, Boar Taint Vaccine for Male Pigs. CSL Limited, Parkville, Victoria, Australia.

Dowsett, K.F., Knott, L.M., Tshewang, U., Jackson, A.E., Bodero, D.A.V., Trigg, T.E., 1996. Suppression of testicular function using two dose rates of a reversible water soluble gonadotropin releasing hormone $(\mathrm{GnRH})$ vaccine in colts. Aust. Vet. J. 74, 228-235.

Dunshea, F.R., Colantoni, C., Howard, K., McCauley, I., Jackson, P., Long, K.A., Lopaticki, S., Nugent, E.A., Simons, J.A., Walker, J., Hennessy D.P., 2001. Vaccination of boars with a GnRH vaccine (Improvac) eliminates boar taint and increases growth performance. J. Anim. Sci. 79, 2524-2535.

Falvo, R.E., Chandrashekar, V., Arthur, R.D., Kuenstler, A.R., Hasson, T., Awoniyi, C., Schanbacher, B.D., 1986. Effect of active immunization against LHRH or LH in boars: Reproductive consequences and performance traits. J. Anim. Sci. 63, 986-944.

Goubau, S., Silversides, D.W., Gonzalez, A., Laarveld, B., Mapletoft, R.J., Murphy, B.D., 1989. Immunization of sheep against modified peptides of gonadotropin releasing hormone conjugated to carriers. Domest. Anim. Endocrinol. 6(4), 339-347.

Hennessy, D.P., Dunshea, F.R., McCauley, I., Colantoni, C., Jackson, P., Long, K.A., Lopaticki, S., Nugent, E.A., Simons, J.A., Walker, J., 2000. Immunocastration - world first boar taint vaccine. In: Proceedings of the $16^{\text {th }}$ International Pig Veterinary Society Congress, Melbourne, Australia, 2000, pp. 315-323.

Janett, F., Lanker, U., Jörg, H., Hässig, M., Thun, R., 2003. Die Kastration männlicher Lämmer mittels Immunisierung gegen GnRH. Schweiz. Arch. Tierheilk. 145, 291-299.

Kohler, I., Moens, Y., Busato, A., Blum, J., Schatzmann, U., 1998. Inhalation anaesthesia for the castration of piglets: $\mathrm{CO}_{2}$ compared to halothane. J. Vet. Med. A 45, 625-633.

Meloen, R.H., Turkstra, J.A., Lankhof, H., Puijk, W.C., Schaaper, W.M.M., Dijkstra, G., Wensing, C.J.G., Oonk, R.B., 1994. Efficient immunocastration of male piglets by immunoneutralization of GnRH using a new GnRH-like peptide. Vaccine 16, 741-746. 
Metz, C., Hohl, K., Waidelich, S., Drochner, W., Claus, R., 2002. Active immunization of boars against GnRH at an early age: consequences for testicular function, boar taint accumulation and N-retention. Livest. Prod. Sci. 74, 147-157.

Oonk, H.B., Turkstra, J.A., Schaaper, W.M.M., Erkens, J.H.F., Schuitemaker-de Weerd, M.H., van Nes, A., Verheijden, J.H.M., Meloen, R.H., 1998. New GnRH-like peptide construct to optimise efficient immunocastration of male pigs by immunoneutralization of GnRH. Vaccine $16,1074-1082$.

Patterson, R.L.S., 1968. 5a-Androst-16-en-3-one: compound responsible for taint in boar fat. J. Sci. Food Agric. 19, 31-38.

Raab, S., Leiser, R., Kemmer, H., Claus, R., 1998. Effects of energy and purines in the diet on the proliferation, differentiation and apoptosis in the small intestine of the pig. J. Metabolism 47, 1105-1111.

Turkstra, J.A., Oonk, H.B., Schaaper, W.M.M., Meloen, R.H., 2002. The role of the individual amino acids of a GnRH-tandem-dimer peptide used as an antigen for immunocastration of male piglets determined with systematic alanine replacements. Vaccine 20, 406-412.

Zamaratskaia, G., 2004. Factors involved in the development of boar taint. Doctoral Thesis, Swedish University of Agricultural Sciences, Uppsala.

Zeng, X.Y., Turkstra, J.A., van de Wiel, D.F.M., Guo, D.Z., Liu, X.Y., Meloen, R.H., Schaaper, W.M.M., Chen, F.Q., Oonk, H.B., Zhang, X., 2001. Active immunization against Gonadotropinreleasing Hormone in Chinese male pigs. Reprod. Dom. Anim. 36, 101-105. 
Lebenslauf

Name

Geburtsdatum

Geburtsort

Nationalität

Heimatort

$1980-1985$

$1985-1990$

$1990-1994$

$1994-1999$

2000

$2000-2004$

im April 2004
Patricia Jaros

22. Juni 1974

Schlieren ZH

Schweiz

Bremgarten AG

Primarschule in Hilfikon, Waltenschwil, Bremgarten AG

Bezirksschule in Bremgarten AG

Kantonsschule in Wohlen AG, Matura Typus E

Studium der Veterinärmedizin an der Universität Zürich

Abschlussprüfung an der Vetsuisse-Fakultät der Universität Zürich

Assistentin am Departement für Nutztiere der Universität Zürich, Abteilung für Schweinemedizin 